\title{
A Study of Vocabularies
}

\section{Edwin W. Doran Ph. D.}

To cite this article: Edwin W. Doran Ph. D. (1907) A Study of Vocabularies, The Pedagogical Seminary, 14:4, 401-438, DOI: 10.1080/08919402.1907.10532555

To link to this article: http://dx.doi.org/10.1080/08919402.1907.10532555

曲 Published online: 30 Aug 2012.

Submit your article to this journal $\widetilde{ }$

III Article views: 12

Q View related articles $₫$

7 Citing articles: 3 View citing articles ๔ 


\section{THE}

\section{Pedagogical Seminary.}

Founded and Edited by G. STanrmy HaLL.

Vol. XIV. DECEMBER, $1907 . \quad$ No. 4.

A STUDY OF VOCABULARIES.

Enwin W. Doran, Ph. D., President, Belvirino College, West Point, Miss.

\section{INTRODUCTION.}

The succeeding pages are offered as a contribution to our knowledge of the following themes.

I. The extent of a person's vocabulary at various periods, from infancy to maturity. We find in literature widely varying opinions, guesses, and estimates as to the number of words a child knows, or has used, or that grown people in the various walks of life use in conversation, business, or in literature. The facts brought out here in regard to the vocabularies of grammar school and high school pupils and college students are the result of investigations in a bitherto little-worked field.

2. The relation of sex to vocabulary; that is, the problem whether a boy or girl, a man or a woman, knows more words, or has the better command of the language. While many people have some opinion on the subject, it is ustually a mere supposition, more often wrong than right.

3. The effect of race, nationality, and climate; or, what the naturalist might term, "geographical distribution;" a fruitful line of investigation for the paidologist or psychologist.

4. The value, or importance, of a good vocabulary. This is discussed in the latter part of the work, together with its relation to successful school work; or, in other words, the correlation between efficiency and the extensiveness of the vocabulary as it relates to school work and public life afterward. Incidentally a discussion arises as to whether we think in words always, chiefly, or not at all.

5. How to secure a good vocabulary. The importance of 
this phase of the subject depends upon the value of a good vocabulary. If it is important to have an extensive vocabulary, it is worth while to give attention to the means whereby such a vocabulary may be secured.

The bibliography appended includes the most important works on all phases of the subject herein treated, and a few topics only briefly discussed, but fundamentally related to the investigation undertaken.

Vocabularies of Chil.dRen.

TABLE I.

Vocabularies of Children.

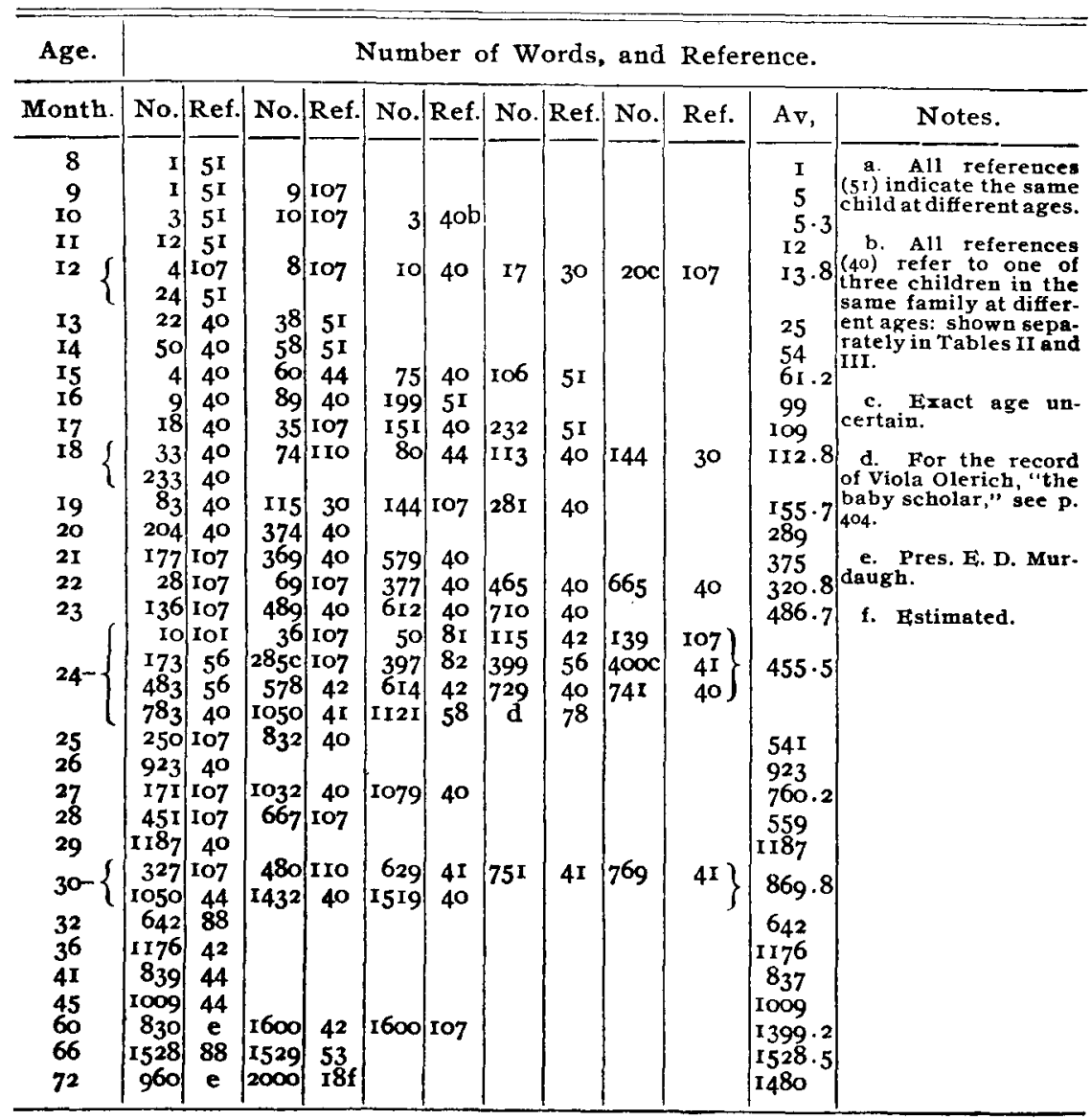


Table I presents in a condensed form all available previously published statistics as to the vocabularies of children below the school age. In the first column are given the ages in months, and in succeeding columns the number of words used by the child at that period, followed by a reference to the source of the information. The numbers in the column marked Ref. refer to the authorities cited in the bibliography at the close, the last column giving the averages for each age. A further discussion of the data of this table with reference to sex will be found in connection with Tables II and III, pp. 415 and 416.

In Table $I$ the vocabularies of over one hundred children are given, including in some cases references to the same child at different ages. The reader will be struck at once with the very great range at any given age. But this is not so strange as at first appears, when it is remembered that some children can scarcely talk at all at two years of age; in fact, occasionally children of average intelligence scarcely talk before they are three years old. Professor Preyer says that he did not learn to speak till he was nearly three years old. (8I.) I have even known of some children of average intelligence that did not talk till they were six or seven years old. Other children have been known to talk before they were eight months old-223d day (5I), some even earlier. The table represents the actual number of words used by the children, proper names of persons and places, generally numerals, nursery rhymes, etc., being omitted. The largest number of records were made, as appears in the table, at the age of two years, and the number of words varies from to to 1,121 , though only three out of the eighteen fall below roo. The average at two years is 455.5 . This is probably fully twice as many as most people would suppose. Of the six who talked at twelve months, the average is almost ten words. The average for the five recorded thirty months old is 705 .

Laurie in his Lectures on Lauguage (65) estimated, in the first edition, that a child up to the eighth year uses only I $_{50}$ words; in second edition he says not more than 200 or 300 ; in the fourth edition he raises bis estimate to four or five hundred. (See 53 and 88.) His trebled estimate is still too small by half. Warner (109) says a child's vocabulary (without specifying a definite age) may be very limited, perhaps not over 200 words. This evidently refers to children four, five, or six years old.

Canton (18) states that a child of six years, of average intelligence, may safely be credited with a knowledge of two thousand words. This estimate was based upon a careful study of the vocabulary of a girl about that age, though he does not give the number of words she used. M. C. and H Gale (42) 
state that 700 words is a typical vocabulary for a two-year-old child. This is considerably higher than the average shown in Table $\mathrm{I}$.

Kirkpatrick (62) says that the number of words used by children two years old varies from a very few words to a thousand, and that the more usual number is from 200 to 400 . This conclusion is based upor a very extensive investigation of the subject; and Table $I$ is in harmony with it.

Preyer (8I) studied the vocabularies of nine children. The smallest vocabulary contained fifty words, the largest I, I 2 I words. The remaining seven children each used from 400 to 500 words.

Viola Olerich, "the famous baby scholar"' (78), at two years of age ( I yr. I I mon. 25 d.) was examined by a committee of school teachers "who found that she knew 2,500 nouns." The committee estimated that she $\mathrm{knew}$ at least 500 more nouns, which they could not present as objects or pictures, making a total of 3.000 nouns (p. 33).

Tracy ( 107 ) found by testing 5,400 children that the nouns form an average of 60 per cent. of the entire vocabulary. A number of other authors give about the same amount. If Viola Olerich knew 3,000 nouns, and this was 60 per cent. of her vocabulary, the total number of words known would be 5,000. This is probably too large. As she was taught nearly altogether by object lessons the nouns would probably represent much more than 60 per cent. of the entire vocabulary; but even at 75 per cent. she would know 4,c00 words, a pretty large number even for a prodigy.

It is very evident that those who have not carefully studied the subject very much underestimate the number of words a child uses, or knows.

In this connection it may be well to call attention to the announcement of a publishing house (B. F. Johnson Publishing Company) to the effect that the first reader of a series they publish contains only 493 words. The first book of the Lee Readers (American Book Company) contains 497 words, exclusive of a few proper names. The average first reader, it will appear, contains practically 500 words. These the pupil of six years is expected to know in addition to the hundreds he knows that are not found in the first reader.

Helen Keller (6I), deaf, dumb, and blind, was $63 / 4$ years old when Miss Sullivan took charge of her. For-weeks she learned words slowly, then began to learn them very rapidly. After this awaking, in less than a month she knew roo words; in two months she knew 300 words; in six months, 600 words; in twelve months, 900 words. She was still less than eight years old. But in a year, with all her disadvantages, she had 
learned 900 words, a larger number than many people would credit to the child of average intelligence at that age with all its faculties intact.

Robinson Crusoe, according to Kirkpatrick (63), contains not fewer than five or six thousand words; yet, as he says, children of ten to twelve years of age understand it.

\section{Vocabularies of Older People.}

Dean Farrar stated, as quoted by Hale (47), that English laborers carry on their conversation with not more than one hundred words. This is a very improbable statement. Max Miiller (75) is authority for the statement that an English clergyman (A. D. Orsey) declares that the laborers in his parish did not use over three hundred words.

W. R. Baird (6) gives the number of words of each part of speech needed by a tourist in a foreign country, the total number being 650 . This is intended to indicate merely what a traveller can barely get along with, and does not represent the vocabularies of the people among whom he travels.

One of the New York papers made the statement that a business man's vocabulary, that is, the words actually needed for business dealings, includes 3,500 words. With the help of a teacher of commercial branches, I counted the words found in a large number of business letters, pertaining to many kinds of business. We found over three thousand words, yet I could readily call to mind scores of words, especially the names of articles of merchandise, not found in our list from the letters. This number would be sufficient, no doubt, for any one kind of business; but if one includes the names of all the principal articles of commerce, it is necessary to double this number.

Perhaps no estimate of the vocabularies of different classes has been more often quoted than that of George P. Marsh. A few of his errors especially have become current. Some thirty years ago he made the following statements $(7 \mathrm{r})$, which were in some respects mere guesses. "Few writers or speakers use as many as ten thousand words, ordinary persons of fair intelligence not above three thousand or four thousand. If a scholar were required to name without examination, the authors whose English vocabulary was the largest, he would probably specify the all-embracing Shakespere, and the allknowing Milton. And yet in all the works of the great dramatist, there occur not more than 15,000 words, in the poems of Milton not above 8,000. The whole number of Egyptian hieroglyphic symbols does not exceed 800 , and the entire Italian operatic vocabulary is said to be scarcely more extensive."

In my own investigations I have had my results frequently called in question by this reference to the vocabularies of Shake- 
spere and Milton. Even if the statements were correct, few people stop to think how the language has grown in the three hundred years since Shakespere's day, and that it is barely possible some modern writers may have used as many words as he, especially as they have written much more voluminously. Most people have not acquainted themselves with the fact that the year Shakespere died (I6I6) the first English dictionary was published, and that it contained just 5,080 words. When Milton died, 58 y ears later, the best English dictionary contained only about i 3,000 words. Of course, not all the words had found a place in the dictionaries of that time; but we all know that many thousands of words have been added to the language, and now some of the dictionaries contain over threehundred thousand words. But these statements of Marsh have been shown to be incorrect, and his estimates very much too low. Dr. Edward S. Holden, who has given much attention to the study of vocabularies, declares (55) that Shakespere used over 24,000 words, basing his opinion on Mrs. Clarke's concordance to Shakespere's works; and that Milton, according to Cleveland's concordance, in his poems alone used I I,377 words. The results of my own studies of a number of authors, given below, support Holden's views.

I. By counting all the words in D. Barren Bright's Concordance to the entire works of Tennyson, I found a total of 10,574 , excluding all proper names not found in the dictionary. Only a few of his minor poems and only a few of his translations are included in this Concordance. Hence this does not include his entire vocabulary.

2. By a similar process, using John Neve's Concordance to the poetical works of Cowper, I found I I,284 words. This Concordance includes only a few of his minor poems, and only a few of his translations. No distinction is made between ditferent parts of speech having the same spelling.

3. In John Bradshaw's Concordance to the poetical works of Milton, there were 12,800 words. This does not include the psalms and translations, or any of his prose works. No distinction is made between parts of speech having the same spelling. This then falls far short of Milton's entire vocabulary. Holden's figures are no doubt more nearly correct. His prose works included with the poetical would add many more words to the list.

4. The Lexical Concordance to the poetical works of Shelley, by F.S. Ellis, includes, according to my counting, 15,959 words.

5. Dr. Edwin S. DuPoncot informs me that he has read all of Victor Hugo's works in the French. He found in Notre Dame, two volumes, over 27,000 words, and estimates that in 
all his works there are 38,000 words. He arrived at these results by counting the words in the vocabularies appended to each work.

These numbers are not incredibly large. If we had a list of the words used by Dickens, Scott, and other voluminous writers, we should no doubt reach similar results.

Holden many years ago made careful tests upon his own vocabulary, using Webster's Unabridged Dictionary (Edition of 1852) to determine how many words he knew. As a result of his count he found he knew 33,456 words. But as that old edition of Webster contained little more than a third as many words as the best dictionaries of the present, and certainly did not contain all the words he $\mathrm{knew}$, his estimate could be safely doubled. Holden further shows (55) that certain men of science know more than 25,000 names of animals or plants; and quotes Dr. Asa Gray, the botanist, and Dr. Theo. Gill, the zoologist, in support of his contention. The New York Times, as quoted by the Pathfinder, Jan. 4, rgoo, states that Rufus Choate used I I, 700 words.

E. A. Kirkpatrick $\left(6_{3}\right)$ found his own vocabulary to consist of nearly 70,000 words, as counted by the dictionary. He further says that to read ordinary general reading one needs to understand from six to ten thousand words. He estimates that a citizen of the United States having a common school education would know Io, 000 words; a well-read college graduate and those who have pursued a university course, would know from 20,000 to 100,000 words.

Several different authors agree in the statement that the vocabularies of intelligent, cultured people, especially of literary taste, contain from 25,000 to 30,000 words. Whitney (III) puts it at 30,000 . Some people know many more than this, as I show by my own investigations on succeeding pages.

It is generally believed that the American Indians, and various other tribes and races of people ranking as uncivilized or partly civilized, have very limited vocabularies.

Chamberlain (20) is authority for the following statements as to the number of words in the vocabularies of the primitive tribes named, basing his statements upon the dictionaries of Indian languages here included:

Navaho (Mathews, 189I), 10,000.

Cree (Vegreville, 1865-1879), I7,000.

Montagnais (Végréville, I891), I8,000.

Dakota (Riggs, 1852-188-), 20,000.

Cegiha (Dorsey, 188-), 20,000.

Black foot (Maclean, I887), 25,000.

Tuskarora (Hewitt, 1886), 30,000.

Micmac (Rand, 1849.94), 30,000.

Yahgan (Bridges, 188-), 40,000. 
Since, as the authors admit, these dictionaries are very incomplete, these estimates, Chamberlain says, are probably too small.

Dr. D. G. Brinton, a very high authority, says (I I) the Mexican vocabulary of Molina contains about 13,000 words, and the Maya vocabulary of the convent of Motul has over 20,$\infty$. Yet these results are taken from old and very incomplete dictionaries.

A. G. Morice (74) in his studies of Déné languages, says the Carrier tribe vocabulary contains 150,000 verbal terms.

Dr. William T. Harris (52) says "the Chinese alphabet having a separate sign for each word, has to be mastered by an enormous effort of the memory, and that ten thousand of these characters are necessary for graduating as a scribe."

\section{Rhsults of my OWN Tests.}

Having brought together in this brief and even fragmentary manner the conclusions reached by numerous other writers as a result of guesses, estimates, tests, and accurate counts, I wish to put on record the results of the investigations $I$ have made during the last ten years. My work has been mainly upon a class of persons not even referred to by any of the authors previously cited; namely, students in schools and colleges. In fact, I have not seen a single reference to any investigations of this kind." My effort has been to ascertain, not the number of words that have actually been used in oral or written speech, but the number of words the persons knew or could use intelligently. Hereafter the word vocabulary will be used exclusively in this sense, unless otherwise stated. And my results have been attained in every case by written or oral definitions. As far as they go they are accurate and reliable, though certain estimates and calculations have been based upon the work done, in which the element of uncertainty may enter; but they are not mere guesses. This explanation seems necessary, since some of the results are a little startling to those who have not looked into the matter.

As there seems to be some confusion in vocabulary tests as to what constitutes a word, let it be understood I have followed the dictionaries in this respect. I have counted what they have counted, and I have included what they have included. For example, the same word as to its spelling, may occur under two or three parts of speech. The pronunciation of the verb and noun is often different as in record, survey, perfume, etc., and the meaning is often very different. In all cases I have included all proper names included in the dictionary and rejected all others. It seems necessary to have some standard in this respect, and it has seemed best to me to follow the dic-

\footnotetext{
1 See reference to later papers, p. 432 .
} 
tionary implicitly. If other writers will do the same, some ambiguity and confusion may be avoided in future. My later investigations have all been based upon the Century and the Standard dictionaries. Some of the earlier tests were based upon Webster's International, the Academic, or the HighSchool editions. My results as to the extent of vocabularies are based upon oral or written definitions, generally of from one thousand to several thousand words. Some conclusions as to the differences with regard to sex were based upon a much smaller number. All class tests were written. I selected all the words on each page, except such unusual words as none would know, and selected the pages either at random, or more often, in a certain order, as every twenty-fifth or fiftieth page. In some cases, especially in the public schools, these tests were carried out by the aid of teachers in charge; yet in every case such tests were written, and the papers graded by me. The tests were mainly given in classes of from ten to thirty, and averages for the class given; but a number of private oral tests were also given of one person at a time.

\section{Class Testrs.}

r. In a village public school, Edmond, Oklahoma, the pupils of the 6 th, 7 th, and 8th grades were tested carefully with the following results for each class :

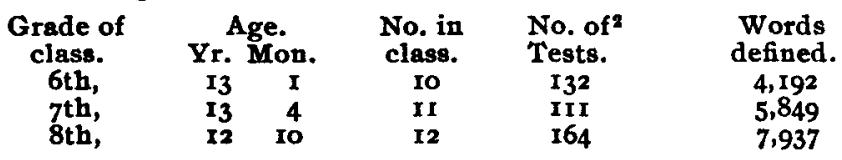

The 8th grade, it will be noted, averaged younger than the 7 th, though they knew many more words. None of these grades, perhaps, were up to the standard of city schools. "Words defined" in the table signifies the average number each member of the class could define.

2. In a village school in Arkansas the following results were obtained.

\begin{tabular}{cc}
$\begin{array}{c}\text { Grade of } \\
\text { class. }\end{array}$ & No. in \\
6th, & class. \\
7 th, & 7 \\
8 th, & 14 \\
9 th, & 20 \\
\hline
\end{tabular}

$\begin{array}{ccc}\begin{array}{r}\text { Age. } \\ \text { Yr. }\end{array} & \begin{array}{r}\text { Words } \\ \text { defined. }\end{array} \\ 13 & 4 & 11,634 \\ 14 & 9 & 13,675 \\ 16 & 5 & 17,138 \\ 17 & 8 & 18,865\end{array}$

It will be seen that the pupils of this school are much older

\footnotetext{
1 The numbers prefixed to tests do not indicate the order in which the tests were made, but are simply for reference.

${ }^{2}$ The number of tests is found by adding all the tests taken by every member of the class.
} 
than those of like grade in test No. I, and they were also graded a little more rigidly; that is, pupils of corresponding grades in No. 2, had really done more work. In test No. I a small school dictionary was used; in No. 2, Webster's International. In the second case the tests were given at intervals for two or three months, and the pupils had frequent drills in defining in connection with spelling lessons. These things account in part for the fact that in one school the vocabularies averaged more than twice as large as in the other.

3. The Oklahoma Normal School at Edmond, had a fiveyear course of study. Tests were given for several weeks to all my classes in connection with their English work, and nearly all the students in the school were tested. I neglected getting the ages, as this was the first test made. The pupils from the first-year class were largely from the country and village schools, and scarcely ranked with the first-year high school pupils generally, though they were older.

$\begin{array}{lc}\text { Class. } & \text { Words defined. } \\ \text { Ist year. } & \text { II,700 } \\ \text { 2d year, } & 15,400 \\ \text { Junior, } & 15,750 \\ \text { Middle, } & 19,400 \\ \text { Senior, } & 21,500\end{array}$

In these results certain small allowances are made for possible errors, and the records are given approximately. The first-year students in this test are scarcely better than 6 th year public school pupils in No. 2, though they were considerably older. This is partly due to the fact also that, as in test No. I a small school dictionary was used-Webster's High School dictionary. The records of second-year, Middle, and Senior are especially good.

\section{INDIVIDUAL, TESTS.}

Having abandoned the class work, except for a comparison of the sexes, ${ }^{2}$ I have made a great many private oral tests; ${ }^{2}$ that is, definitions were given orally and included from five hundred to five thousand words each. The result was arrived at, as in class records, by multiplying the average number of words defined on each page by the whole number of pages in the dictionary.

4. A little girl in Oklahoma, two years old, was observed

\footnotetext{
In this test, made ten years ago, I have retained only brief summaries, and neglected to record the number in each class, but give the average number of words defined by each pupil for what it may be worth.

See pp. 414-426.

8 I formed the acquaintance of a parrot that could speak 59 words. Gardner says that apes have a vocabulary of 25 or $3^{\circ}$ words.
} 
for about two weeks and her words noted by members of the family. They recorded only I6I words. It is not certain that this included all the words she had used. As I knew the child well, I felt sure her vocabulary was less than 200 words, as she did not talk very well.

5. Pearl Beale, a little girl almost five years old (59 months), knew on 100 pages of the Student's Standard Dictionary 171 words, an average of $\mathrm{I} .7 \mathrm{I}$ words to the page. This, multiplied by 814 , the number of pages in the book, gives $I, 39 \mathrm{I}$ words. While a very intelligent girl, her opportunities for securing a large vocabulary had not been good. She spoke German, but I did not test her German vocabulary.

6. Foster Brown, a boy nine years old, tested in the same way, apparently knew 6,03I words. He was an unusually bright boy in many respects, and had an excellent command of language in conversation; but he had not been to school much, and was in the third grade.

7. My own boy, Edwin B. Doran, at ten years of age could define at least 10,000 words. He had read a good many books, and associated largely with older people. When he was thirteen years old, having read at least a hundred books, and having had one year of Latin and considerable practice in vocabulary work, he could define about 18,000 words. This statement may appear incredible to some, but it is based upon extensive and careful tests.

8. A young lady ig years old, who had not quite finished the literary course in a young lady's seminary, tested by the use of the Student's Standard Dictionary, apparently knew 20,537 words. But with one of the large dictionaries the result would have been much higher.

9. A physician, in Little Rock, Ark., 30 years old, who had not taken a college course, other than his medical course, tested with the International Dictionary, knew 57,154 words.

Some tests have been made on the students of the James Millikin University. While most of the tests were made by classes to determine the effect of sex upon vocabulary, the following five were private tests more extensive than the others. The Standard Dictionary was used. ${ }^{1}$

ro. Miss Alice Finfrock, second-year Academy, 23, 100 words.

II. Miss Augustine Southworth, third-year Academy, 26,600 words.

\footnotetext{
1 By the kindness of President A. R. Taylor, I had opportunity to test, in addition to members of my own classes, representative students and classes from all departments of the university, though for lack of time I did not make as complete an investigation as I wished.
} 
12. Mr. Paul S. Welch, fourth-year Academy, 4I,895 words.

13. Mr. E. J. Witzemann, Junior, college, 40,68I words.

I4. Mr. E. A. Meserve, Junior, college, 53, I30.

Most of these, perhaps all of them, ranked above the average of the class, as far as I was able to test the members of the class. These all took other tests in class, the results of which are not included in these records. Mr. Weich's record is especially good, as he is still in the academy department. Mr. Meserve so far, heads the list. Probably few, if any, in the university could surpass him. But Miss Finfrock's record, considering the fact that she is only it years old, is remarkably good. These five had nearly the same list of words, some more than others. The largest number of words given was about 4,000. A further discussion of these results will be found in the latter part of this paper.

The following are recent individual tests made upon young people in Jackson, Miss. The figures given are estimates based upon a list of nearly two thousand words. All had the same words, except that a few missed some of the tests.

Name.

Sallie Ligon,

Emily Harper,

Mollie Smith

Elain Ward,

Osborn Young,

Archie Owen,

Minter Gant,

\begin{tabular}{rr}
\multicolumn{3}{c}{ Age. } \\
yr. & m. \\
I4 & 8 \\
I1 & 9 \\
I5 & 8 \\
I3 & 3 \\
12 & 8 \\
I3 & 3 \\
12 & 9
\end{tabular}

Words.

I I, 340

12,516

14,595

18,753

22,722

26,376

28,480

These results, especially for the last three, are very high. These three boys have very remarkable vocabularies, ranking with advanced college students whom I have tested on some of the same words.

I5. The best vocabulary I have ever found, so far as any extensive test has been made, is that of Miss Rosa Rhee Kevil (now Mrs. A. F. Crider, whose husband is State geologist of Mississippi). She spent some months in Decatur last fall and I had opportunity to make a very full and careful test. The result of the test showed she could define 92,161 words. A careful test was made on three different occasions. While there was considerable variation from page to page as to the number of words defined, yet taking the results of each test separately the averages were almost the same, varying less than half of one per cent. As in perhaps every test given, the record of the first part of the test was the lowest.

16. It will not be amiss, I trust, for me to put on record some tests upon my own vocabulary, as several other writers have doue. Ten years ago, when I first became interested in 
the subject, I made a pretty extensive test of my own knowledge of words, using the Century Dictionary. The result of the test showed I could define about 84,000 words. But I feel sure I have outgrown that. I noticed especially in Miss Kevil's test that I could define many words she could not. Hence I feel that $I$ am not immodest in estimating my vocabulary at 100,000 words. Though the test with the dictionary did not show this, it is borne out by the fact that I know thousands of words not found in any one dictionary. For a number of years I have been making a study of the common, or vernacular, names of animals, especially of Vertebrates and Insects. In this study it is necessary to know both the techuical and the vernacular names. By a careful consultation of the dictionaries with reference to all these names, I believe I know four or five thousand technical and vernacular names in Zoölogy alone which are not found in any dictionary. Botany and other sciences add many more to the list.

17. But I wish to put on record another case, in some respects the most remarkable of all. My friend, Edwin S. DuPoncot, Ph. D., of the Utah State Normal School, is a comparatively young man, but a language expert. He has a working knowledge of more than twenty languages. He has given a good deal of attention to the number of words in the various languages, and to his vocabulary in each. At my request he has furnished the following estimates of the number of words he knows in the several languages :

\begin{tabular}{|c|c|c|c|c|c|}
\hline \multirow[t]{2}{*}{$\begin{array}{l}\text { English, } \\
\text { French, } \\
\text { German, } \\
\text { Spanish, } \\
\text { Italian, } \\
\text { Latin, }\end{array}$} & \multirow[t]{2}{*}{$\begin{array}{l}70,000 \\
50,000 \\
45,000 \\
35,000 \\
25,000 \\
20,000\end{array}$} & \multirow[t]{2}{*}{$\begin{array}{l}\text { Portuguese, } \\
\text { Old French, } \\
\text { Greek, } \\
\text { Old H. Ger., } \\
\text { Norwegian, } \\
\text { Swedish, }\end{array}$} & \multirow[t]{2}{*}{$\begin{array}{r}15,000 \\
10,000 \\
10,000 \\
5, \infty 00 \\
3,000 \\
3, \infty 00\end{array}$} & \multirow[t]{2}{*}{$\begin{array}{l}\text { Danish, } \\
\text { Sauskrit, } \\
\text { Anglo-Saxou, } \\
\text { Hebrew, } \\
\text { All others, } \\
\quad \text { Total, }\end{array}$} & $\begin{array}{l}3,000 \\
2,000 \\
2,000 \\
1,000 \\
3,000 \\
\end{array}$ \\
\hline & & & & & \\
\hline
\end{tabular}

These estimates seem most remarkable, and to some, no doubt, incredible. It does not at first seem possible that any one man could know 300,000 words. But since Dr. Du Poncot speaks some of the modern languages as fluently as he speaks English, though born in the United States, it is not strange that his vocabularies in those languages should be almost as large as his English vocabulary. For example, he has won no little renown in lecturing in Spanish to Spanish-speaking people. His estimate of his English vocabulary is certainly not unreasonable.

We often see the statement that the modern languages in general have a much smaller number of words than English; but Dr. R. J. Kellogg, head of the modern language department of the James Millikin University, recently informed me that in his opinion such languages as the French, the German, 
and the Spanish have practically as many words as the English; for there is scarcely a word in English that does not have its equivalent in those languages, and every thought of an Englishman may be expressed by a German, a Frenchman, or a Spaniard.

But we should remember that the 300,000 words noted do not represent as many different ideas, since many of them are mere translations of the same word, though often, of course, with some variation in meaning. At any rate, this is a very remarkable vocabulary.

In a recent article in the Popular Science Monthly ( 5 a), Prof. E. H. Babbitt gives the following estimate of his own vocabulary, counting all compounds given in the dictionary:

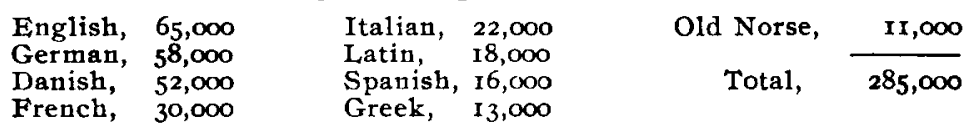

He says these may be reduced to twenty or thirty thousand actual roots.

\section{The Relation of Sex to Vocabulary.}

We may now look at the matter from an altogether different point of view. In recent years a number of works have appeared on the mental and physical characteristics of the sexes. Ellis (33), Thompson (IOI a), Thorndike (I05), and a number of others, have enumerated hundreds of differences between the sexes in the various stages of maturity. But few publications have appeared as to the differences in the sexes in regard to vocabularies; in fact, almost nothing except the studies of concepts of children; and most authors who have written on the vocabularies of children have laid little stress upon the subject of sex, and in many cases the sex was not even given, the word child being used. The following pages are offered as in some sense supplying this gap in our knowledge of sex.

I have asked many people their opinion as to which sex has the better vocabulary. In nearly every case the female is credited with a more extensive vocabulary than the male. But the results of my studies are not very favorable to this opinion.

Reworking the material in Table I (page 402), I have presented the records of each sex separately, as far as the sexes are known; in Table II (p. 4I5), the boys' vocabularies, and in 'Table III (p. 4I6), the girls' vocabularies. These two tables give 48 records of the boys and 63 records of the girls, ages ranging from 8 months to 72 months. The average number of words for the 48 boys is 531.4 ; for the 63 girls, 404.3. This seems to favor the boys, but considering the ages, we find the boys average 27 months; the girls, 23 months. Hence the 
boys average four months older. Ten of the girls, or 15.8 per cent., are over 24 months old, while 20 of the boys, or 4r.6 per cent., are over 24 months old. There are only two or three periods in which there are enough of each to enable one to arrive at any definite conclusion. At the age of 24 months, there are eight boys with an average of 367.2 words and 16 girls with an average of 573.x words, thus giving the girls an excess of 206 words, or 56. I per cent. At 30 months there are five boys with an average of 838 words, and three girls with an average of $1,109.3$ words, an excess of 30.9 per cent. As there are so few of any age except 24 months, about all we are war-

TABLE II.

Vocabularies of Boys. (48.)

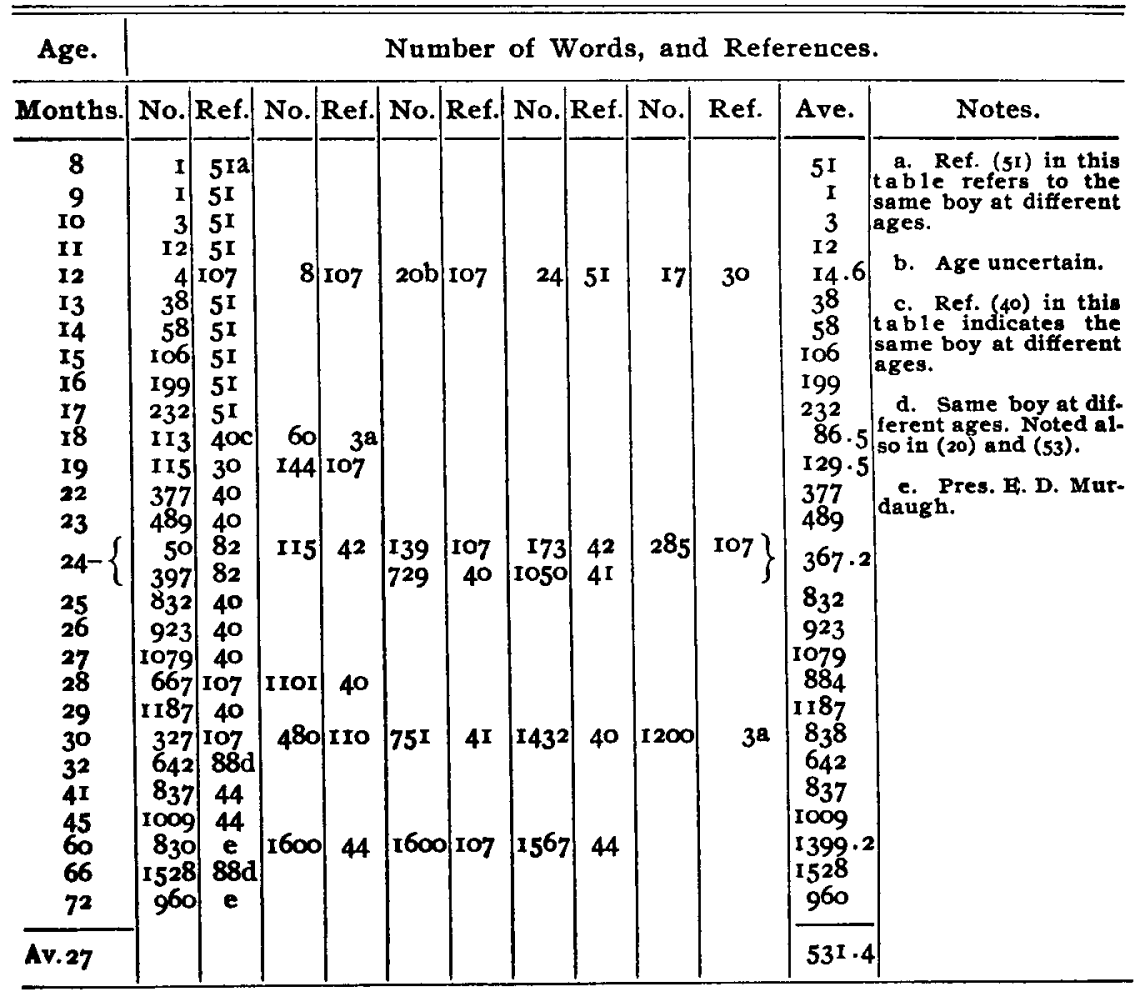

ranted in saying is that at that age the girls studied have an excess of more than 50 per cent. over the boys. The ro boys also aged 25 to 30 months averaged 887 words, while the 7 
TABLE III.

Vocabularies of Girls. (63.)

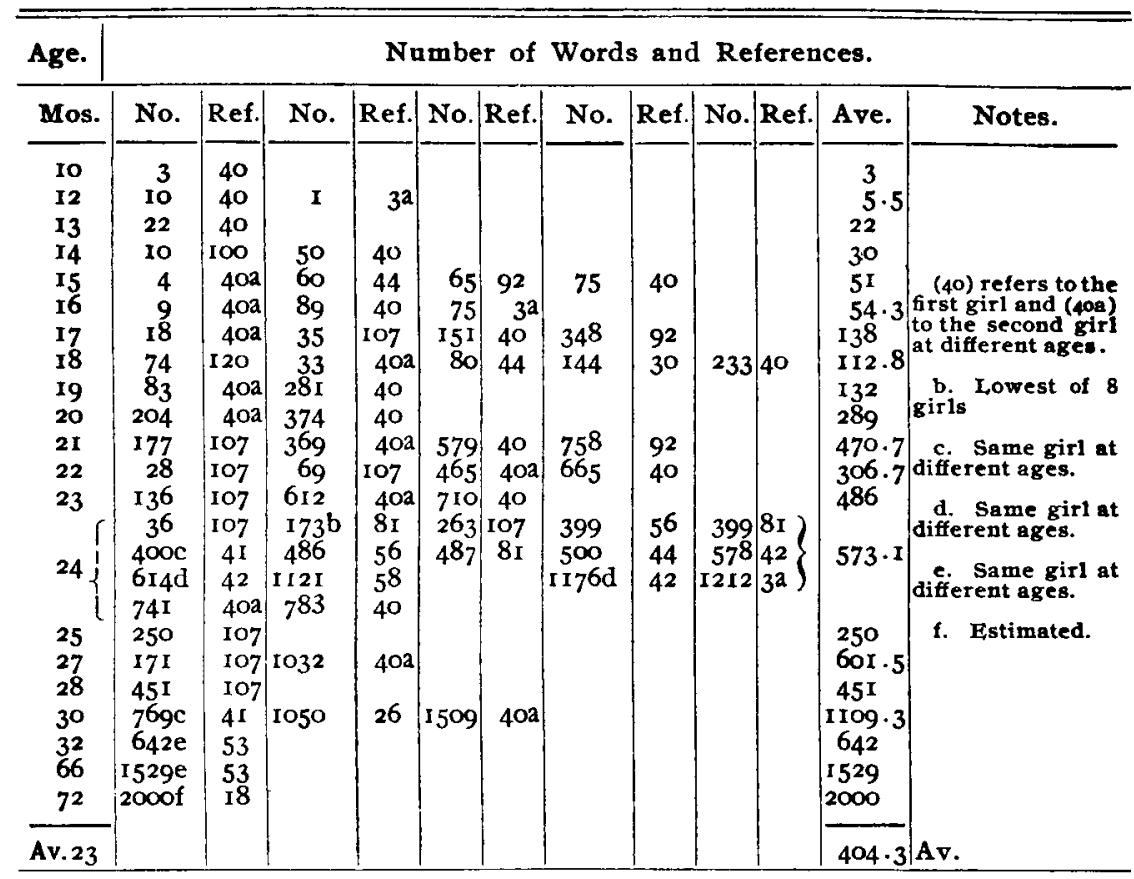

girls for the same period averaged 747 words; and the 19 boys over 24 months averaged I, 022 words, while the ro girls for the same period averaged 940 words. But the 3 girls over 30 months averaged $I, 390$, and the 9 boys over 30 months averaged only I, I 75 words. Hence, without further information, we are not warranted in saying which has the better vocabulary after the 24th month, though it is probable that further investigation will show the girls surpass the boys up to the fifth or sixth year.

Reconsidering class test No. I, p. 409, the Edmond, Okla., public school, and arranging as to sexes, the following results are obtained :

\begin{tabular}{|c|c|c|c|c|}
\hline $\begin{array}{c}\text { Grade. } \\
6 \text { th, } \\
7 \text { th, } \\
8 \text { th, }\end{array}$ & $\begin{array}{c}\text { No. pupils. } \\
5 \\
6 \\
2\end{array}$ & $\begin{array}{cc}\text { Boys. } \\
\text { Age. } \\
\text { I2 } & 9 \\
\text { I3 } & \text { I } \\
\text { I2 } & 0\end{array}$ & $\begin{array}{c}\text { No tests. } \\
66 \\
66 \\
28\end{array}$ & $\begin{array}{c}\text { Words. } \\
4,783 \\
6,553 \\
8,210\end{array}$ \\
\hline \multicolumn{5}{|c|}{ GirLS. } \\
\hline $\begin{array}{l}\text { 6th, } \\
\text { 7th, } \\
\text { 8th, }\end{array}$ & $\begin{array}{r}5 \\
4 \\
\text { ro }\end{array}$ & $\begin{array}{ll}13 & 4 \\
13 & 7 \\
13 & 8\end{array}$ & $\begin{array}{r}66 \\
45 \\
136\end{array}$ & $\begin{array}{l}3,985 \\
5,745 \\
7,736\end{array}$ \\
\hline
\end{tabular}


COMparison.

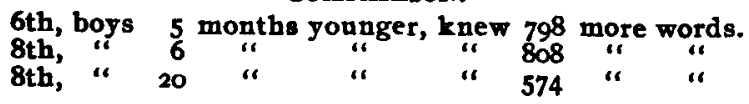

These results are rather remarkable. Though the boys averaged more than ro months younger, they knew II.9 per cent. more words. The boys of the 8th grade (only two) were younger than any other class, but they knew more than twice as many words as the girls of the 6 th grade, who were 20 months older.

19. Reworking the material of the Arkansas public school (No. 2, p. 409) the following are the results as to the sexes:

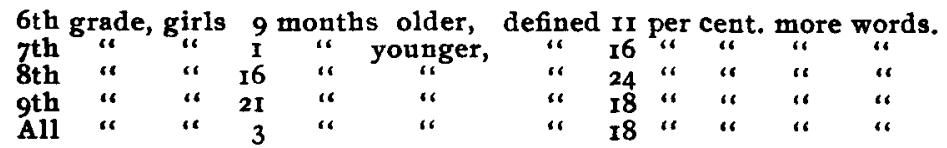

This test seems as conclusive in favor of the girls as the last was in favor of the boys. The test includes 44 girls and 22 boys. The girls were very much better students than the boys.

20. Returning to the test of the students of the Oklahoma Normal School (No. 3, p. 4ro) I present the following comparison of the sexes. ${ }^{1}$

\begin{tabular}{|c|c|c|c|c|c|c|c|}
\hline $\begin{array}{l}\text { First-year } \\
\text { Second-year, }\end{array}$ & boys & $\underset{\text { knew }}{\text { kn }}$ & $\begin{array}{r}4 \\
11\end{array}$ & per & cent. & more & words. \\
\hline Junior, & or & 18 & $2 I$ & of & 11 & 66 & 11 \\
\hline & 16 & $\|$ & 20 & "c & -1 & $a$ & $" r$ \\
\hline Senior, & IC & .t & $1 / 2$ & ac & 10 & II & a \\
\hline es & 16 & ir & I I & 66 & 11 & lo & "r \\
\hline
\end{tabular}

This seems very conclusive in favor of the young men. The senior class had only two young men and four young ladies. The other classes were much larger.

The results of other tests are given in more condensed form.

21. About 50 students, nearly equally divided as to sex, in the Kansas Normal School, at Fort Scott, were tested. The young men averaged 2 months younger, and knew ro per cent. more words.

22. In the Clinton Normal School, Clinton, Mo., about 20 students of each sex were tested. The young men averaged 14 months younger, but knew 7 per cent. more words.

In Kay County, Oklahoma, Summer Normal, lasting four weeks, tests were made upon two classes of teachers (a firstgrade class and a second-grade class), about 25 teachers in each class, with the following results:

23. First-grade teachers, 6 male, 20 female; the young men were 4 years younger, but knew I I per cent. more words.

In this and a number of the following tests the actual ages were not obtained. 
24. Second-grade teachers, 5 male, 20 female; the young men were 2.6 years older, and knew 30 per cent. more words.

25. In the Oklahoma County, Okla., Summer Normal, lasting four weeks, a test was made on 72 teachers, 26 male, 46 female. The young men knew 26 per cent. more words.

26. A rather limited test was made upon a dozen students of the Century Normal College, Ky. The girls were 10 months younger and knew 5 per cent. more words.

27. In McEwen College, Tenn., I4 students of the same class were tested, 8 boys, 6 girls; the girls knew ro per cent. more words. In another class of 7 girls and 2 boys, the girls knew about 50 per cent. more words. The boys were behind the class, but about the same age.

Recent tests were made upon the students of the James Millikin University; but the results were not very satisfactory, because the tests were too few, and not many students were reached in some classes. However, as there was no time for further tests, I present this, as in some respects the most unsatisfactory of the records made in this paper. An eight-year curriculum is provided; four years in the academy, and four years in the college. As far as possible I give the results of each class, showing the per cent. of excess one sex had over the other.

28. First-year Academy, the young men knew 89 per cent. more words than the young ladies; only one-third as many young ladies took the tests.

29. Second-year Academy, the young men knew 30 per cent. more words.

30. Third-year Academy, the young ladies knew 29 per cent. more words.

3r. Fourth-year Academy, only one young lady took the test, but she made a lower record than the lowest among the young men, and they averaged 50 per cent. higher than her record.

32. Freshman class, the young ladies average 13 per cent. higher; but nearly twice as many ladies took the test.

33. Sophomore class, about four times as many young ladies as young men took the test. The young ladies averaged onefourth of one per cent. better.

34. Only a few juniors of either sex were examined, but the young men averaged $2 \mathrm{I}$ per cent. higher.

35. Only three seniors took any of the tests, hence no value can be attached to the results. The one young lady did a little better than the average of the two young men.

The honors seem nearly equally divided. In five of the classes the young men were ahead, in the others the young ladies made the better record. But some of these records are 
nearly valueless, as stated above, because so few tests were given, and so few took some of the tests. Putting all classes together, the results are more satisfactory, as that makes eight times as many tests, or eight times as many students in the tests, as the average for each class. Summed up in this way, the young men of all classes averaged i I per cent. higher than the young ladies. Then taking the average advancement of all the students, the young men averaged 3.3 years in school, the young ladies 4.2 years. This shows, therefore, the young ladies tested were nearly a year more advanced than the young men; yet the young men made, on the whole, decidedly the better record. Moreover, it happened, I believe in every test, taking all the young men together of all grades, and the young ladies of all grades, the young men made the better record. This is significant as being based upon the same list of words.

A series of tests were made upon the children of the Jackson, Miss., public schools. Supt. E. L. Bailey and several of the teachers very kindly aided in carrying out the investigations. My work was confined to the fourth, fifth, sixth, and seventh grades of white schools, and sixth, seventh, and eighth grades of colored schools. These are the only tests, as far as I know, that have ever been made upon children in the negro schools. I hope to extend these investigations to other negro schools, but not in time to include the results in this paper.

A list of twenty words was submitted to the pupils in all these rooms on the same day, under the direction of the teachers; the meanings of these words were written. The papers were graded by myself on a scale of roo per cent.; that is, each correct answer was marked 5 , and partially correct answers from 4 to $I$.

In order to verify certain results, especially in the colored schools, a second list of twenty words was submitted to all the rooms before tested in the negro schools, and to the sixth grade in the white schools. This list, taken from a magazine, consisted of seven nouns, five verbs, four adjectives, and four adverbs, and the pupils were required to define them in accordance with the parts of speech. As the records of the two tests were essentially alike, they are combined in the results here given. The ages were taken in years and months.

In some of my earliest tests, several years ago, only correct answers were marked, while a little later credit was given for partly correct answers, though not so fully as in these tests.

36. White schools, first test.

$4^{\text {th }}$ Grade, 16 boys and 17 girls; the girls were 4 months older, and knew 15.8 per cent. more words.

5 th Grade (a), I6 boys and I 6 girls; the boys were 4.2 months older, and knew 4. I per cent. more words. 
$5^{\text {th }}$ Grade (b), 6 boys and 12 girls; the boys were 9.5 months older, and knew 4.9 per cent. more words.

6th Grade, 29 boys and 12 girls; the girls were 1.5 months younger, and knew 3 / to per cent. more words.

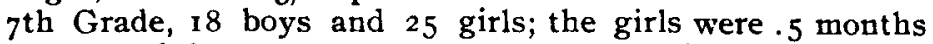
younger, and knew 14.1 per cent. more words. Averaging, the boys were 8 months older, and knew 3.5 per cent. more words. The average includes 16 girls, 6 th grade, in another room, making a total of 85 boys and 98 girls.

37. Colored schools, first test.

6 th Grade, 8 boys and 16 girls; the boys were 8.5 months younger, and knew I. 3 per cent. more words.

7 th Grade, 3 boys and I 4 girls; the boys were 9.5 months older, and knew 4 per cent. more words.

8th Grade, 8 boys and 5 girls; the girls were I 3.6 months older, and knew 3.2 per cent. more words.

Averaging, 19 boys and 35 girls; the boys were 2.3 months younger, and knew 3.7 more words.

Averaging, white and colored, 104 boys and I 32 girls; the boys were 8 months younger, and knew 5.8 per cent. more words.

38. A summary of both tests combined.

White schools, I I 4 boys, 109 girls.

The boys averaged 2.2 months younger, and knew 5.8 per cent. more words.

39. Colored schools, 39 boys, 76 girls (both tests combined).

The boys were II.5 months younger, and knew .3 per cent. more words.

A comparison of the vocabularies of the white and negro children would no doubt be of considerable interest, but I find some people object to any comparison of this kind. On the same principle, of course, one could object to a comparison between native and foreign-born children, or Southeru and Northern children. I have no sentiment, nor even any opinion, to express in the matter; I present a few facts, the result of $\mathrm{my}$ investigations.

But as the tests were not applied to corresponding grades entirely in the two schools (4th to 7 th in the white, and 6th to 8 th in the colored), I shall compare only the 6th and 7 th grades of each, giving averages.

40. The 137 white children, both sexes, were 13 years and 2.5 months old, and defined 85 per cent. of the words; the 85 negro children, both sexes, were I 4 years and ro months old, and defined 83.5 per cent. of the words; or, the white children of the two grades were 19.5 months younger, and knew 1.8 per cent. more words.

Probably few people would expect the negro children to 
make so good a record. While they average nearly two years older, Supt. E. L. Bailey informs me the grades in the two schools do not correspond exactly; that is, the 6 th grade in the white schools is a little more advanced than the 6th grade in the negro school. But this only adds to our surprise that the vocabularies of the negro children are so high. It should be stated, however, that the pupils in the colored schools had been drilled upon definitions, especially on prefixes and suffixes, and this particular school, without doubt, ranks above the average negro school even in the cities of the south.

The 6th grade in the white school, in charge of Miss Duling, had also had special drills of the same kind, and made a remarkably high record, the highest of any corresponding grade I have ever tested, and considerably higher than the 7 th grade in the Jackson school.

4I. I present lastly a study of the vocabularies of I 39 pupils in the negro schools of Meridian, Miss. ${ }^{1}$ The second list of twenty words submitted in the Jackson public schools was used with these pupils, so that the results of the same grades are readily comparable. I give a brief summary of each class.

$3 \mathrm{~d}$ grade, 18 boys and 27 girls : the girls were 9.6 months younger, and defined ro. 6 per cent. more words.

$4^{\text {th }}$ grade, I I boys and 29 girls: the girls were 5.1 months younger, and defined 6.8 per cent. more words.

$5^{\text {th }}$ grade, 4 boys and 19 girls: the girls were 16 months older, and defined 8.5 per cent. more words.

6th grade, 7 boys and 24 girls: the girls were 8.3 months younger, and defined $1 / 4$ per cent. more words.

Combining all grades, we get the following results : 40 boys were I 2 years 8.9 months old, and defined 47.9 per cent. of the words. 99 girls were 12 years and 4.9 months old and defined $6 \mathrm{c} .2$ per cent. of the words. In all grades, therefore, the girls were four months younger, and defined 25.7 per cent. more words. This large per cent. in favor of the girls over the boys is partly due to the fact that the boys were more numerrous in the lower grades.

Comparing the Jackson and Meridian negro schools, the records are not greatly different.

6 th grade, the only one that permits comparison, 6 Jackson boys were I 4 years, 6.5 months old, and defined 77.8 words. 7 Meridian boys were 14 years 5 . I month old, and defined 81.3 words. The I I Jackson girls of this grade were 12 years 3.8 months old, and defined 99 per cent. of the words; while the 24 Meridian girls were 13 years 8.8 months old, and defined

\footnotetext{
test.

${ }^{1}$ I wish to acknowledge the aid of Supt. J. C. Fant in making this
} 
81.5 per cent. of the words. The Jackson girls were 17 months younger than the Meridian girls, yet defined 22 per cent. more words.

\section{Summary of Sex Tests.}

The reader by this time is no doubt very much "at sea," and nothing definite seems to have been arrived at. But by recalling all the facts in the case three very definite and rather surprising facts are brought out.

First, it is very probable from all information at hand that up to the fourth or fifth year the girls know or use more words than the boys.

But what can we say of all subsequent ages or classes? In the majority of cases the boys knew more words than the girls.

Reviewing tests Nos. I 8 to 40 , it will be seen examinations have been made in I I schools (including teachers' summer normals), and all together 34 classes have been tested separately, if we include some of the very incomplete tests in the James Millikin University. Of the eleven schools tested as to sex, males made the higher record in eight of them. Considering the 34 classes, males made the better record in 22 , in addition to the fact that in the Jackson schools the boys made the highest total averages in the white schools, negro schools, and white and negro combined.

Considering the geographical distribution of the schools, it will appear that seven of the eight schools in which males made the better record are in the North, except those in Oklahoma, which is really more northern than southern as to population; that is, many more of its settlers come from tbe north than from the south. Note again that all those schools, except one, in which the young ladies made the better record are in the South. From all my observations and tests, from an extensive experience as a teacher both north and south, I feel warranted, therefore, in drawing two more conclusions:

Second, in northern schools the male students in the same classes or of the same age know more words than the female students.

Third, in southern schools the female students in the same class or of the same age generally know more words than the male students. This is not true in the Jackson schools, which is the only exception I have found.

Several other incomplete tests, the data from which are not included in this report, tend to a confirmation of these very unexpected results.

In this connection the careful and extended experiments of Dr. G. Stanley Hall (49), to determine the contents of children's minds on entering school, are especially interesting. Of 
the various concepts upon which the children were tested he found that the boys knew more of three-fourths of the concepts than the girls.

The easy and widely diffused concepts are commonest among the girls, the harder and more special or exceptional ones are commonest among boys. The girls clearly excelled in, name and calling of father, thunder-shower, oak, dew, Botanical Garden, rainbow, hail, potato-field, moon, square, circle, and a few others. The girls also excelled in fairy tales, while the boys excelled in religious concepts. In the Boston schools he found the girls excelled in knowledge of the parts of the body, home, and family; and that their stories were more imaginative. But their power to sing and articulate correctly from dictation was distinctly less than that of the boys, as well as their acquaintance with numbers.

The author gives in this discussion the experiments of Dr. K. Lange on 500 city children and 300 country children. The girls had seen, heard, and experienced less of sixteen out of seventeen subjects.

In the Kansas City schools the boys knew more of 34 questions out of 49 than the girls. The Irish children were behind the American children, but the Irish girls decidedly outrank the Irish boys.

He gives also the tests at Annaberg schools by Hartman on 660 boys and 652 girls with 100 questions ; ages $5 \frac{8}{4}$ to $6 \frac{8}{4}$ years. The girls excelled in 56 questions, the boys in 38 . The girls also excelled the boys in marks the first three years. The sixth year the boys were distinctly ahead.

Monroe (6I) in testing the perception of school children secured results which seem to differ somewhat from the results just recorded. Hesubmitted cancelled two-cent postage-stamps to 2,191 children, directing them to write an account of the stamp. Returns were made by 985 boys and 1,206 girls, ages ranging from 7 to 17 years. The following are his conclusions:

"Sex differences are the most marked feature of the study. It will be noted that in all the essential lines of observation the girls lead the boys ; they not only tell more about the stamp, but in many instances their observation shows a higher order of intellectual discrimination. They seem to surpass the boys in their knowledge of the postage stamp; and they certainly surpass the boys in their ability to tell what they know about the stamp."

Professor Barnes asks in this connection, "Does this apparent superiority of the girls mean that they are better observers than the boys, more studious than the boys, or have better powers of expression than the boys?"

Unfortunately we are not informed as to average age of the 
boys and girls. It is possible the girls were older and more advanced than the boys. We cannot assume they were of the same age, or that equal or proportionate numbers of each were taken from the same classes. In nearly all my tests the girls averaged older than the boys.

Chambers sent out to the teachers of Minnesota, to be submitted to their pupils, the following words: monk, peasant, emperor, armor, nation, school. (The same words used by Prof. Earl Barnes (8) in England and the Eastern States.) He got papers from 2,922 pupils; ages, 6 to 18 ; boys, 1,365 ; girls, 1,567 ; American born, boys 4r9, girls 494; foreign born, boys 946 ; girls 1,063 . The author says that as to sex the girls excel the boys both as to correct and partially correct answers, and adds: "Is not this what we should expect? Girls are everywhere more attentive to details and distinctions than are boys. The common interests of their lives centre more about little things," etc.

This is not what I have been led to expect for pupils of all ages, as is shown by the results of most of my tests. However, it is worthy of note that 68.7 per cent. of the pupils were foreign born, and as it is shown in the Kansas City schools (26) that the Irish girls, that is, those of Irish parentage in most cases, were decidedly superior to the Irish boys of the same age, this may be true of other foreigners; and as there were more than twice as many of foreign birth as of American birth, the foreigners would easily control the results as to sex, and decide the test in favor of the girls. It would be interesting to know the results of each class, foreign and native, separately as to sex.

The American children of Minnesota were like the American children of Kansas City, decidedly superior to the foreign in the tests made. The author says : "It is altogether probable that this difference is due less to race characteristics than to home customs. Studies of children's vocabularies prior to school age show clearly that children of cultured American parents use correctly a much larger number of words than children of American parents of less culture." It is pointed out that the investigations of Miss Dismorr, in London, in schools attended by children of laborers and small shop-keepers and schools attended by children of the middle classes showed that the children of the latter were far superior in their knowledge of words.

All these results except the last are in harmony with my conclusions as to vocabularies. Up to a certain age, about the $5^{\text {th }}$ or 6 th year, the girls are decidedly superior to the boys, but after that time the boys are as distinctly superior to the girls. In Dr. Hall's tests, made the first year the children were in 
school, the ages of none, perhaps, were less than six years. In Hartmann's tests some were under six, and the girls were ahead; but after six the reverse was true. But a striking fact is that among the Irish children the girls were ahead even after six. This anomaly as to nationality is similar to the peculiarity found as to geographical variation, and both suggest a fruitful field for further inquiry.

It is not unusual that one sex surpasses the other in certain characteristics or attainments at one period of life, while the conditions may be reversed at another stage. In the tests upon the perceptions of children by Monroe, referred to above, there are several illustrations of this. In studying the postage stamp eight points were noted: color, portrait, substance, form, use, perforation, size, and cancellation. Concerning two of these the girls surpassed the boys at all ages, while the boys were superior at all ages as to one point. Concerning five points the girls were superior at an early age but lost to the boys at a later period, but in one of these the boys fell behind the girls again. The ages at which these changes occurred were from 9 to 16 , but mostly from 14 to 16 . In the one case in which the boys surpassed all the time, there was a sudden increase in gain at 15 years.

\section{General Considerations.}

The foregoing statements based upon the investigations made by myself and others require some further discussion and restatement. The statement of a fact should be accompanied by a reason for the fact, or an explanation of the fact, unless the matter be entirely plain to all.

\section{The Influence of Sex.}

During the first five or six years of child-life why should girls use more words, or know more words, or have a greater number of concepts than boys? After this period why should the conditions be almost universally reversed? Why should we find an exception to the rule south of the Ohio River? Why should we find another exception in the case of the Irish children, as brought out by Hall? Why, in short, should sex, or climate, or nationality, or geographical distribution, have any bearing upon the superiority or more rapid development of one sex over the other? It is not easy to answer all these questions.

As to sex,-it is generally conceded that the girls develop more rapidly in infancy, as is shown by the preceding tables. Boys talk but little under 24 months. This will account for the superior vocabularies of the girls during the first few years; but as the girls continue to mature more rapidly than the boys, this will not account for the fact that the boys generally sur- 
pass them as to extent of vocabulary after they have reached the school age, as shown by my experiments and Dr. Hall's. And what makes the matter still more remarkable is, that in nearly all my investigations, taking pupils, students, or teachers of the same class or grade, the males were younger, sometimes very much younger. This comparative meagerness of the vocabulary of the "gentler sex" seems in direct contrast to the popular opinion that girls, or young women, are better talkers. or have a certain fluency of speech not possessed by the "sterner sex." But this does not imply that woman has a better choice of words. Her proverbial "last word" in the argument may be only a repetition of the first word. The number of words necessary for polite and even animated conversation is very small, - a few thousand at most. A much more extensive vocabulary is required for public adoress. This is the reason, perhaps, that men are generally better speakers than women; and the reason I may say, in passing, that some men may appear fairly well in conversation, but cannot succeed as public speakers.

Why Man has the Better Vocabulary.

I use the term man somewhat generically, so that it includes the boy. After children have reached the age of four or five years, the boy is out of doors more than the girl. He sees more, hears more, and seems to take more interest in the affairs of the great world in which he lives. He asks thousands of questions, he pries into the secrets of nature. In this way he gets many more ideas than the girl who spends most of her time in playing with her dolls and talking doll-language, which requires only a very meager vocabulary. Thus, the first one or two years spent largely out of doors has brought up the limited vocabulary of the small boy to that of the girl of his age. He continues his method of life, on the street, in the field or shop, still the great irrepressible question-asker. The girl, a little later, may go into "society" more, she may read more books, especially more fairy-tales or light novels; but these do not animate her as do the blood-curdling stories of adventure that the boy delights in. At a little later period he reads the daily or weekly newspaper more than she does, and becomes acquainted with the parlance of politics, commerce, and the affairs of the world generally. This, I think, is sufficient to account for his knowing more words than girls of the same age.

EXCEPTIONS TO THE RULE.

Having arrived at a somewhat satisfactory reason for the two contentions, that during the periods of childhood below the school age the girls know more words than the boys, and 
that after that time the reverse is true, how shall we account for the apparent fact that in the South the girls continue to have the better vocabulary during the entire public school course, as shown by most of my experiments; and that the Irish girls know more words than the Irish boys, at least during the first years of school, as shown by the investigations in the Kansas City schools? I should call attention to the fact, perhaps, that the Kansas City test was one of concepts rather than words; but, while one may have concepts which be has not succeeded in naming, I think, in general, there will be found substantial agreement as to the comparative number of words and concepts, as I hope to show later.

Perhaps as to the cause of these two apparent exceptions I should do myself credit by simply saying, I do not know; but I am unwilling to let it go at that.

Having lived and taught many years in the South I have come to the conclusion that the southern boy is more polite, genteel, and docile than the northern boy; but be is less virile, less versatile. I should not say he is more feminine, but less ruggedly masculine. Hence he differs somwhat as to the qualities of his maleness, so to speak. I say this, though mindful of certain characteristics that develop later in life in the southener. The traits of character less dominant in the boy under the sunnier skies are the very ones that have made the boys of the north more bold, aggressive, and interrogatory, and have caused them to pick up more words than their sisters.

On the other hand, the southern girl is more precocious, more daring, more animated than her cousins across the Ohio. She sees more of out-door life, and is freer from the trammels of the nursery. She develops earlier than the boy, and continues to beat him on his own ground, for a number of years. Without detracting from her charms, her femaleness is less feminine in her early years. I believe these characteristics are sufficiently marked to account for the differences I have noted.

Having had the opportunity of observing the Irish a good deal in school work, I have noticed that the Irish boy is slow and plodding. The proverbial Irish wit evidently developed late in the history of the race, and, speaking as a biologist, it is likely to develop late in the life of the individual. The boy in his native isle develops slowly and the mind is sluggish. These characteristics apply to the girl somewhat also; but in common with other girls she develops faster than the boy, and on account of the tardy quickening of his mental powers, he is a longer time in catching up with his sisters than is the American boy. If information were at hand, we would no doubt find that the boy at a little later period gathers himself together, and widens his scope of knowledge, so that he comes to know 
more words than girls of the same age. I do not think the characteristics peculiar to the southern boy and girl apply to the Irish children.

\section{How to Securf a Goon Vocabulary.}

The word good may be used in a broad and comprehensive sense to include not only an extensive vocabulary, but a wellselected vocabulary, just as a good library should contain not only many books, but good and wholesome books.

The vocabulary of the child depends very much upon the home. The child in the home of refinement and culture will certainly gather up more words and get more ideas-and the two are nearly synonymous, as I hope to show later-than in the home lacking in culture and intellectual atmosphere. This is brought out in Miss Dismorr's London experiments.

A constant association with other children of about the same age is an incentive to the little one to talk, and a child so situated will hear more language suited to its capacity than the child bronght up in isolation. The character of the vocabulary is often greatly modified by nurses and servants. These in many cases are not only ignorant and unrefined, but often superstitious and sometimes vicious. Southern children, many of them left almost completely in the care of colored nurses, are especially unfortunate in this respect. Corrupted pronunciation, slang, the names of mysterious, fanciful beings which strike terror to the heart, and sometimes profanity, are learned at an early age, and produce a lasting impression upon the child. The man fifty years of age has not entirely rid himself of the pernicious linguistic acquisitions of the nursery. The child's vocabulary may be greatly increased by parental encouragement to ask questions about what it sees and hears. The child is a bundle of interrogation points, and the parents who answer all reasonable questions and encourage the child to ask more, thus increase greatly its stock of ideas and the words which represent these ideas. A well-selected lot of picture-books, playthings, etc., which the child is interested in, undoubtedly adds to the words it may have in store.

At a later period the reading of books and papers bas much to do with the number and quality of the storehouse of words at the command of the boys and girls. The number of books is not so important as the quality and the state of mind with which they are read, and the pains taken to learn the meaning of what is read. I have made it a practice to inquire as to the kind and number of books read by those tested, and I am led to believe that the potency of the good book read with a dictionary at one's elbow can scarcely be overestimated. But contact with the world in society, business, and travel must not be neglected. 
I have taken some pains to ascertain what text-books and school exercises contribute most to the forming of one's vocabulary. One of these is word-analysis, whether given in connection with English work, or in the spelling-class. The study of roots, stems, primitives, derivatives, prefixes, suffixes, etc., gives the pupil a knowledge of words he can scarcely get in any other way in the grades. An accurate knowledge of a few prefixes and suffixes will put the pupil in possession of hundreds of words of which before he had no definite conception. This is brought out in connection with my tests in the Jackson schools, especially in the sixth grade, white, and sixth and seventh grade, negro schnols.

Spelling may be made a most valuable exercise in this respect. It was my custom as a teacher in the public schools to require pupils of all ages to spell, and to know the meaning of the words they spelled. Why should we ever learn to spell a word whose meaning we do not know? We cannot make any use of the word until we grasp its meaning. It is vastly more important to know the meaning than to know the spelling ; for we may correctly use a word orally which we cannot spell. In fact most people speak a hundred words to one they write.

I commend the exercise described by Supt. J. M. Greenwood in an article on Spelling (45). He says: "I had bought a second-hand copy of Webster's Academic Dictionary. . . . I took up Webster's Old Blue Book, and I marked down all the words between its two covers of whose meaning I had any doubts. There were sixty-eight of these words, and I hunted up their meanings in this dictionary. I had never looked into a dictionary of any kind a dozen times in my life before, and yet I was 'shaky' on only sixty-eight out of about 10,000 different words in that book." This shows he had a pretty good vocabulary for a young teacher of those days (it was during the first term he taught), and that he had learned how to increase his vocabulary.

The study of English, of course, is one of the most valuable exercises for increasing one's vocabulary. Though nearly twohundred years have passed, Benjamin Franklin's method has scarcely been improved upon. I quote from President Charles W. Eliot in Science for June ist, 1906. "To improve his vocabulary he turned specimens of prose into verse, and later, when he had forgotten the original, he turned the verse back again into prose. This exercise enlarged his vocabulary and his acquaintance with synonyms and their different shades of meaning, and showed him how he could twist phrases and sentences about." Composition work of every kind is very valuable, 
especially if one takes any pains to use just the right word. Much depends upon the teacher in this.

Every school exercise should contribute somewhat to one's stock of words. No word in the reading, history, geography, or other subject, should be passed over until the pupil understands it. If this practice is begun in the lower grades, there will be few words to study in any one lesson.

The study of Latin, and to a less extent, Greek, and other languages, contributes greatly to the growth of the student's vocabulary. Nearly one-third of all the words in the English language are derived from the Latin. A large number, especially scientific terms, come from the Greek. No one who hopes to understand English can afford to neglect Latin. In making the test on Mrs. Crider's vocabulary (see No. I5) I found three different pages of the dictionary on which she did not know a single word. These pages were filled with scientific terms derived from the Greek, and she had not studied Greek. She had a fine training in Latin, and this put her to the front of all those tested, yet two or three years in Greek would have added thousands of words to her vocabulary. Even one or two years in Latin or Greek are valuable in this respect. One who has worked out carefully the conjugation of a dozen Latin or Greek verbs has learned new meanings to hundreds or even thousands of English words. Mr. Meserve, who made the best record in the James Millikin University, has had five years of Latin, five of French, two of Greek, two of German, and one of Spanish.

But above all and at all times, make constant reference to the dictionary. The student should never allow the dictionary to get beyond his reach, as he sits at his study table. Have a stand or table especially for it, and always keep it open and in the most accessible position. Form the "dictionary habit" early in life; in later life one will have such a storehouse of words one will not need it so much. If a word is mastered when met, then it will reappear hundreds and thousands of times, like the face of an old and long-loved friend.

Vocabulary tests themselves have proved to be one of the most important means of increasing one's vocabulary. After one has tried writing definitions to a few score even of the most familiar words, and found how difficult it is to give a definition that really defines, one begins to make a more careful study of words. In every case where I have given extended written tests the student has shown great improvement in his mastery of words. There should be almost daily tests in classes upon words from spellers, readers, histories, etc., and often upon words that have not been assigned for previous study. Every pupil in school should have a small dictionary of his own, 
while an International, the Standard, or the Century is accessible to all when necessary for a fuller study of words.

IMPORTANCA OF A GOOD VOCABULARY.

An old grammar studied in my boyhood days says, "A word is a sign of an idea." One of the best of the modern dictionaries says a word is "used as a symbol to embody and signify an idea or thought, especially a notion or conception." If then a word is a sign of an idea, the more words one knows, the more ideas one has. When, therefore, a man has added a thousand words to his vocabulary, he has put away in the pigeonholes of his brain a thousand thoughts or ideas-ready servants to do his bidding. If a man has a new thought, then, or a new concept, he must at once search about for a word to embody that thought. A word is an incarnate thought. If there is no word in which to house his thought, he must make one, that his ideas may not wander about like disembodied spirits.

This calls up the old discussion as to whether we think in words only. I do not wish to thrash out that subject again, yet it deserves some attention. Fitch in his lectures at Cambridge University ( 38$)$ says : "Every word which has been invented is the record of some fact or thought, and furnishes the means by which facts or thoughts can be transmitted to others. In a sense, every new word represents a new conquest of civilization, a distinct addition to the intellectual resources of the world."

Laurie in his Lectures on Language (65) says: "For in adding to his [the child's] stock of understood words, we add to his stock of understood things, and, consequently, to his material for thought and to the growth of the fabric of the mind."

Prof. Max Müller, in his Science of Language (75), makes this statement: "No buman being utters articulate sounds without an object, a purpose, a meaning. The endless configurations of sound which are collected in our dictionaries would have no existence at all, they would be the mere ghost of a language, unless they stood there as the embodiment of thought, as the realization of ideas." (Vol. 2, p. 5r.)

President A. R. Taylor (IOI), speaking of children's vocabularies, says: "Their knowledge and vocabularies grow at approximately the same rate, and revealing also the function of language in knowledge-getting." The child's words are stepping-stones to knowledge, and represent the ability to get knowledge, whether or not they represent so much knowledge.

Whether we can think without words or not, it is certain that no connected train of thought is carried on independently of the symbols of thought. Therefore, by increasing the num- 
ber of words at our command, we increase the number of concepts of the mind.

How a judicious selection of words enhances the interest in a speaker or writer! But he cannot make a judicious selection unless he has an extensive list to choose from. Precision, clearness, and elegance of diction are impossible with a man who has a limited vocabulary. A man who is not able to say directly what he wishes to say, talks in circumlocutions, in his effort to reach a given point. Has any one ever stopped to calculate how many misunderstandings, broken friendships, law-suits, and divorces result from an ignorance of the meaning of words? Lawyers, litigants, judge, and jury, wrestle in a vain attempt to interpret a carelessly worded contract or statute. If men had the power to discriminate in the use of words, and other men had the power to interpret them with nicety, this would be a far happier world.

Correlation Betwefn Grades and Vocabularies.

For a long time I have noticed that the students who rank high in their classes nearly always have good vocabularies; and looking at it from the other point of view, that those who have good vocabularies rank high in their classes. As this correlation between vocabularies and grades had been almost universally true, as far as I was personally acquainted with the work of those tested, I desired to verify the matter more fully in the James Millikin University by consulting teachers as to the standing of pupils, and by carefully comparing my vocabulary tests with my class records and with those records of work kept in the office. I found a marked parallelism between the two sets. It matters little whether we say students do well because they have good vocabularies, or they have good vocabularies because they do well; it matters little which is cause or which effect, -it follows that if you increase a student's vocabulary you increase his standing in his class. The one who has a vague, ill-defined knowledge of words, bas vague and illdefined thoughts, and is incapable of definite, systematic, and logical thinking. If a word is a sign of an idea, bungling, meaningless expressions indicate a clouded, vacant brain.

Two recent articles in the Popular Science Monthly, one by Prof. E. A. Kirkpatrick (64a), the other by Prof. E. H. Babbitt (5a), exhibit plans and results very similar to my own, previously recorded in this paper. Professor Kirkpatrick suggests that as the extent of the vocabulary indicates so nearly the mental ability of the student, a vocabulary test might possibly be used as an examination for entrance to college. Professor Babbitt announces that he has successfully used this test with several classes in German instead of an examination for 
entrance to second-year work. Those who knew from 2,000 to 5,000 German words were able to carry the work. At the end of the second year they could define from 5,000 to 12,000 German words.

\section{Mere WordS.}

"Words fitly spoken are like apples of gold in pictures of silver." Words whether audible or representing only the ideas that flit from brain-cell to brain-cell, become photographed upon the memory and mold character. The words we use both indicate and help to fix our characters. There is a reciprocal relation between our words and ourselves. Evil words flow from an evil source, and likewise an evil source begets evil words.

What potency in words! They are sufficient to express the most entrancing poetry, the sublimest oratory, the profoundest philosophy; the most soul-blighting grief, or joy supernal ; the most transcendent thoughts of priest or seer or incarnate Divinity. A word may be a message of love which shall make glad the heart, or a messenger of despair which shall blast the life. A word may unlock the gates of the Celestial City, may express the song of the angels and the redeemed around the throne, or may bear through infinite space the thoughts of the Eiternal.

\section{BibLIOGRA PHY.}

I. Adams, Cecerica. Hindrances to the Development of Language. Proc. N. E. A., Ig02, pp. 4I2-4I7. Also Kindergarten Mag., Sept., 1902, Vol. I5, pp. 20-24.

2. Al, LE, MARGaret A. A Mother's Journal. Babyhood, March, I885, Vol. I, p. II3.

3. - Notes on the Development of a Child's Language. Mothers' Nursery Guide, Feb., 1893, Vol. 9, p. 90.

4. Alvarez, Machado $Y$. Titin: A Study of Child Language. Trans. of the Philological Soc. of Lon., 1885-87. pp. 68-74.

5. Amanr, W. Die Entwickelung von Sprachen und Denkenbeim Kinde. Wunderlich, Leipzig, r899. pp. 2 r3.

5a. Babbir', E. H. A Vocabulary Test. Pop. Sci. Mo., April, I9o7, Vol. 7o, p. 378 .

6. BAIRD, WILliam R. The Study of Languages. Memory, MayJune, I89I.

7. Baldwin, J. M. Mental Development in the Child and the Race. Macmillan, New York, rgo3. pp. 496.

8. Barnes, EarL. How Words Get Content. Barnes' Studies in Education, April, Igo2, Vol. 2, pp, 43-6r.

9. Bentuy, ElLA H. Sex-Differences that Have Been Brought Out by Child Study. Northwestern Mo., I897, Vol. 8, pp. 25726 I.

Io. BRinton, Daniel G. The American Race. Hodges, New York, I89r.

II. I89r. Essays of an Americanist. Porter \& Coates, Phila., 18go. pp. 487 . 
12. Brinton Daniel, G. Races and Peoples. Hodges, New York, I89o. pp. 313.

13. Brown, Eirza BeTh STowe. The Baby's Mind: Studies in Infant Psychology. Babyhood, I89o, Vol. 6, p. 340.

14. BuckinhaM, Elinor M. Vocabulary of School Children. Nation, 1900, Vol. 7I, p. 270

15. Buckman, $S$. S. The Speech of Children. Nineteenth Cen., I897, Vol. 4I, pp. 792-807.

16. Burneam, W. H. The Study of Adolescence. Ped.Sem., r89r, Vol. I, pp. I74-I95.

17. Canfinld, W. B. The Development of Speech in Infants. Babyhood, May, 1887 , Vol. 3. p. 186.

18. Canton, William. W. H.: Her Violets. McClure's Mag., 1897, Vol. 9, pp. 884-89o.

19. ChamberLain, AleXander F. Notes on Indian Child Language. Amer. Anthropologist, I890, Vol. 3, pp. 237-24I; 1893, Vol. 6, pp. $321-322$.

20. Pp. $321-322$. The Child: Study in the Evolution of Man. Scribner, New York, 1902. pp. 498.

2i. Chamberlain, A. F. and Isaber, C. Studies of a Child. Ped. Sem., Sept, and Dec., I904. Vol. I I, pp. 264-292; 452-483; Dec., 1905, Vol. 12, pp. 427-453.

22. Chambers, Will, Grant. How Words Get Meaning. Ped. Sem., March, I904, Vol. I I, pp. 30-50.

23. Chrisman, $O$. The Secret-Language of Childhood. Century, I 898 , Vol. 56, pp. 54-58; also The Secret Language of Children, Northwestern Mo., I897-98, Vol. 8, pp, I87-19.3, 375-379; 649-65I; also in Science, 1893, Vol. 22, pp. 303-305. also Children's Secret Language, Child Study Mo., 1896, Vol. 2, pp. 202-2II.

24. Colfins, J. The Genesis and Dissolution of the Faculty of Speech; a Clinical and Psychological Study of Aphasia. Macmillan, New York. I 898.

25. Compayré, J. G. The Intellectual and Moral Development of the Child. Appleton, New York, I896. pp. 298. (Internat. Educ. Ser. v. 35.)

26. - L'Évolution mentale et morale de 1'Énfant. Hachette, Paris, i89. pp. $37 \mathrm{I}$.

27. Conrad, FDward. Children's Interests in Words, Slang, Stories, etc. Ped. Sem., Sept., 1903. Vol. Io, pp. 359-404.

28. Psychology and Pathology of Speech-development in the Child. Ped. Sem., Sept., I904. Vol. II, pp. 328-380.

29. Darwin, Charles. Biographical Sketch of an Infant. Mind, July, 1877, Vol. 2, pp. 285-294.

3o. Dewey, John. Psychology of Infant Language. Psychol. Rev. Jan., I894, Vol. I, pp. 63-66.

3r. DILlARD, J. H. The Literary Taste of Pupils and theit Vocabularies. Nation, I900, Vol. 7 I, p. I89.

32. EGGER, E. Observations et Réflections sur le Développement de 1'Intelligence et du Langage chez les Enfant. Picard, Paris, 1887. pp. 102.

33. Ell, IS, Ha VkLOCk. Man and Woman. Scribner, New York, I897. pp. 409. (Contemp. Sci. Ser. $\nabla .24$.)

34. - Studies in the Psychology of Sex. Davis, Phil., 1903. pp. 275

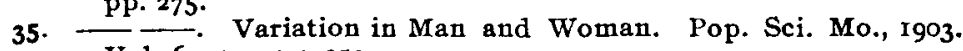
Vol. 62, pp. 237-253.

36. Erdmann, B. Die Psychologischen Grundlagen der Beziehung zwischen Sprechen u. Denken. Arch. f. Syst. Philos., 1896, Vol. 2, pp. 355-4I6. 
37. Farrar, F. W. Language and Languages. Chapters on Language and Families of Speech. New York, 1887.

38. Fitch, J. G. Lectures on Teaching. Macmillan, New York, 1889. pp. 393.

39. Frankf, C. Sprachentwickelung des Kindes und des Menschen. Rein's Encyclop. Handbuch d. Päd., I899, Vol. 6, 757-794. (Bibliography.)

40. GaI, H. Vocabularies of Three Children in one Family. Psychological Studies, July, I900. No. I, pp. 70-I I8.

4I. - M. C. and $\mathbf{H}$. Vocabularies of Children. Pop. Sci. Mo., 1902, Vol. 7I, pp. 45-57.

42. Vol. 9, pp. 422-435.

43. Galton, F. and others. Thought without Words. Open Court, I887, Vol. I, p. 44I; 472; 498 .

44. Grennwoon, J. M. Seventeenth Annual Report of the Kansas City Public Schools, 1887-88.

45. How I Learned to Spell. The School Jour., Igo6. Vol. 72, pp. 368-37o.

46. Gutzmann, H. Des Kindes Sprache und Sprachfehler. Leipzig, 1894. pp. 264 .

47. HalE, Horatio. The Origin of Languages and the Antiquity of Speaking Man. Proc. of the Amer. Assoc. for the Adv. of Science, 1886, Vol. 35 , p. 279.

48. - Language as a Test of Mental Capacity. Trans. of the Royal Soc. of Canada. I891, Vol. 9, pp. 77-II2.

49. Hall, G. Standey. The Contents of Children's Minds on Entering School. Princeton Rev., 1893, Vol. 9, pp. 249-272. Also Ped. Sem., 1891, Vol. r, pp. I38-173.

50. - Notes on the Study of Infants. Ped. Sem., I89r, Vol. I, pp. $127-138$.

5r. Hall, Mrs. W.S. The First 500 Days of a Child's Life. ChildStudy Mo., 1896-97, Vol. 2, pp. 320, 394, 458, 522, 686, 650.

52. HaRRIS, WiLliam T. Editor's Preface (in Rosenkranz, J. K. T. The Philosophy of Education. Appleton, N. Y., I903, pref., PP. 5-II).

53. Hinsdale, B. A. Teaching the Language Arts. Appleton, New York, 1899 (Internat. Educ. Ser., v. 34).

54. Hogan, Lovise E. Study of a Child. Harper, New York, 1898. pp. 219.

55. HoLDEN, EDWARD S. On the Number of Words used in Speaking and Writing. Bull. of the Phil. Soc. of Wash., 1874-1878. Vol. 2.

56. - - On the Vocabularies of Children nnder Two Years of Age. Trans. of the Amer. Phil. Assoc., I877, pp. 58-68.

57. Hookfr, N. S. The School Boy's Vocabulary. The Nation, 1900, Vol. 7I, p. 210.

58. Humphrays, M. W. A Contribution to Infantile Linguistics. Trans. of the Amer. Phil. Soc., I880. Vol. II, pp. 6-I7.

58a. JEGI, JoHN I. The Vocabulary of a Two-year-old Child. Child Study Mo., Igor, Vol. 6, pp. 24I-26r.

59. Jorrston, C. The World's Baby Speech. Fortnightly Rev., Vol. 1896, N. S., Vol. 6o, pp. 494-505.

6o. Krane, A. H. Ethnology. Cambridge University Press, Cam. bridge (Eng.), r8g6. pp. 442-444.

6I. KELLER, HHLEN. Story of my Life. Doubleday, New York, I903. pp. 44I.

62. KIRKPATRICK, E. A. How Children Learn to Talk; a Study of the Development of Ianguage-Children's Vocabularies. Science, I89I, Vol. 18, p. 175. 
63. Kirkpatrick, E. A. The Number of Words. in an Ordinary Vocabulary. Science, $x 891$, Vol. I8, p. 107.

64. - Promising Line of Child Study for Parents. Trans. 111. Soc., for Child Study, 1899, Vol. 3 , pp. 179-182.

64a. - A Vocabulary Test. Pop. Sci. Mo., Feb., I907, Vol. 70, pp. $157-164$.

65. LAURIH, S. S. Language and the Linguistic Method. 4th Ed., Edinburgh, rgo3.

66. LEFìvRE, A. Race and Language. Appleton, New York, 1894. pp. 424.

67. LukmNS H. T. Language Defects. Northwestern Mo., r897, Vol. 8, pp. 39-44.

67a. 8, Pp. 39-44. Correspondence. Am. Jour. of Psy., Oct., 1898, Vol.

Io. pp. I63-I64.

68. - Preliminary Report on the Learning of Languages. Ped. Sem., June, I896, v. 3, pp. 424-46o.

69. Maknen, G. Hubson. Speech as a Factor in the Diagnosis of Backward Children. Jour. of Psycho-Asthenics, March-June, I902, Vol. 6, pp. 80-83.

7o. MarcelL, ClaUde. Study of Language Brought Back to its True Principles. Appleton, N. Y. pp. 448, 467. (Humbolt Library, v. I.)

71. Marsh, Giorge Perkins. Lectures on the English Language. Scribner, Armstrong \& Co., New York, 1872 .

72. Monroz, Will S. Perception of Children. Ped. Sem., Dec., I904, Vol. II, pp. 498-507.

73. - Bibliography of Education. Appleton, New York, I897. pp. 202. (Internat. Educ. Ser., v. 42.)

74. Morice, A. G. The Dènē Languages. Trans. of the Canadian Inst., I899-90, Vol. I, pp. I70-2I 2.

75. MÜLL,ER, F. MAX. The Science of Language. Scribuer, New York, I89I. 2 vols.

76. NightenGALE, EIENOK M. Close thinking and Accurate Speech. School Jour., 1904, Vol. 68, pp. 378-379.

77. Noble, EDmund. Child Speech and the Law of Mispronunciation. Education, 1888, Vol. 9, p. 44; I I 7 ; 188 .

78. Olerich, Henry. Viola Olerich, the Famous Baby Scholar. Laird \& Lee, Chicago, Igoo.

79. Pollock, F. An Infant's Progress in Language. Mind, 1878, Vol. 3, pp. 392-40I.

80. Porter, SAMUEL. Is Thought Possible without Words? Princeton Rev., I88I, Vol. 7, pp. IO4-128.

81. Prayer, W. The Senses and the Will, Part $I$, of his Mind of the Child. A ppleton, New York, I893. See, especially, p. I 70.

82. The Development of the Intellect. Part II, of his Mind of the Child. Appleton, New York, 1889. See, especially, p. 317 .

83. RHODES, LiL,IAN IONF. Bibliography of Child Study. Board of Educ. Phil., I902. pp. I28.

84. Ribot, Theoddie. Abstraction prior to Speech. Open Court, I899, Vol, I3, pp. 14-20.

85. - Evolution of Speech. Open Court, 1899, Vol. I3, pp. 267-278.

86. Robinson, L. The Primitive Child. North American Review, I894, Vol. 159, pp. 467-478.

87. Romanes, Geo. J. Mental differences between men and women. Nineteenth Cent., I887, Vol. 2I, pp. 654-672.

88. SAl.rsbury, AlBERT. A Child's Vocabulary. Educ. Rev., 1894, Vol. 7, pp. 287-29o. 
89. SawVkL, Frankit B. Ethics of a Vocabulary. Education, I895, Vol. 15, pp. 489-492.

9o. Schurrza, F. Die Sprache des Kindes. Funker, Leipzig, 189o. pp. 46.

91. Shinn, Milimicent W. Notes on the Development of the Child. University of Cal. Studies, 1893-94. 2 v.

92. - - Vocabularies. Child Study Mon., and Jour. of Adolescence, April, Igor, Vol. 8, pp. 398-40r. Also Univ. of Cal. Studies, I893-1899.

93. Smith, Margaret K. The Psychological and Pedagogical Aspects of Language. Ped. Sem., Dec., I903, Vol. 3, pp. 438-458.

94. Strvanson, A. The Spcech of Children. Science, 1893, Vol. 21, p. 118 .

95. STUMPF, C. Eigenartige Sprachliche Entwickelung eines Kindes. Zeits. f. Päd. Psy. u. Pathol., rgor, Vol. 3, pp. $420-447$.

96. Sully, James. Baby Linguistics. Eng. Illus. Mag., Nov., I884, Vol. 2, p. I 10 .

97. - - Genius and Precocity. Pop. Sci. Mo., 1886, Vol. 29, pp. $469-482 ; 494-606$.

98. - Studies of Childhood. Appleton, New York, 1896. pp. 527 .

99. TAINE, H. Acquisition of Language by Children. Mind, April, 1877, Vol. 2, pp. 252-259.

roo. TANnkR, Amy Eliza. The Child: His Thinking, Feeling, and Doing. Rand, McNally \& Co., Chicago, 1902. pp. 3r4-338.

ror. TAylor, AlBert R. The Study of the Child. Appleton, New York, 1899. p. 86. (Internat. Educ. Ser., V. 43.)

rora. Thompson, Hel.en BRADFord. Mental Traits in Sex. Univ. of Chicago Press, Chic., I903. pp. I88.

102. Titchener, E. B. A Psychophysical Vocabulary. Amer. Jour. of Psy., Oct., 1895, Vol. 7, pp. 78-85.

103. THorNDIKE, EDWARD Lite. Hereditary Correlation, and Sexdifferences in School Abilities. Columbia Univ. Contrib. to Philos. Psy, and Ed uc., rgo3, Vol, Ir, No. 2, pp. 60.

104. - Notes on Child Study. Columbia Univ. Contrib. to Philos. Psychol. and Educ., 1903, Vol. 8, No. 3-4, pp. I8I.

105. - - The Study of Children, Teachers' College Record, New York, May, rgor, Vol. 2, pp. 165-I75.

106. Tracy, FreDerick. The Language of Childhood. Amer. Jour. of Psy., Oct., 1893, Vol. 6, pp. ro7-121.

107. - Psychology of Childhood. 2d ed. Heath, Boston, I904. pp. 170.

108. TRETTIFA, A. W. Psychology of the Language Interests of Children. Ped Sem., March, I904, Vol. I I, pp. II3-r77.

rog. WARner, Francis. The Study of Children, and their School Training. Macmillan, New York, I897. pp. I20-I2I.

Iro. Watson, Mary AgNES. Children's Vocabularies. Paidology, Jan., rgor, Vol. I, pp. 227-237.

III. WHITALY, WILLIAM D. Language and the Study of Language. Scribner, New York, 1891. pp. 18-20

112. - L, Life and Growth of Language. Appleton, New York, 1875. pp. 25-26.

r13. WICkrerstim, JAmes P. Method of Instruction. Lippincott, Philadelphia, 1866.

Ir4. Wrrson, L. N. Biblography of Child-Study. Ped. Sem., April, 1898, Vol. 5, pp. 54r-589; Sept., 1899, Vol. 6, pp. 386-4Io; Dec.. rgoo, Vol. 7, pp. 526-556; Dec., Igor, Vol. 8, pp. 513-537; Dec., rgo2, Vol. 9, pp. 521-542; Dec., I903, Vol. ro, pp. 514-536; Sept., .I904, Vol. II, pp. 292-327; Sept., I905, Vol. I2, pp. 304-333; Dec., Igo6, Vo1. I3, pp. 374-397. 
I15. WoLFE, H. K. On the Color Vocabulary of Children. Nebraska Univ. Studies, July, 1890, Vol. I, pp. 205-234.

116. WolfF, FAN EY E. A Boy's Dictionary. Child Study Mo., Sept., I897, Vol. 3, pp. I4I-I5o.

I17. WROE, MARGARET A. Sex in Education. Child Life, April, 1904, Vol. 6, pp. 74-78.

II8. YODHR, A. H. Sex Differentiation in Relation to Secondary Education. Proc. N. E. A., I903, Pp. 785-792.

Nork. The author has published several short articles, dealing generally with a single phase of the subject. The following may be of interest: Annual Report of the Oklahoma Normal School, Edmond, 1896; giving tests in that school; Self-Culture Magazine, Oct., 1898, general; Mississippi School Journal, March, 1907, giving tests in public schools of Jackson, Miss. 